\title{
CONTENT OF BACHELORS' IN TOURISM INFORMATIVE TRAINING IN UKRAINIAN AND POLISH EXPERIENCE: COMPARATIVE STUDY
}

\begin{abstract}
This article provides a comparative analysis of the content of Bachelors' in Tourism informative training in Ukrainian and Polish experience. The content of Bachelors' in Tourism informative training in Ukraine and Poland has been analyzed. The content of subjects, namely, "Information Technologies in Tourism" and "The Foundations of Bachelors' in Tourism Information Culture" being the basis of Bachelors' in Tourism informative training in Ukraine has been justified. It has been concluded that the study of foreign experience in specialists' professional training, in particular, specialists' in tourism, that requires critical analysis of achievements in education systems abroad and outlining of positive aspects of such experience, is extremely necessary for the development of higher education in Ukraine as the implementation of new information technologies into educational process creates optimal conditions for the forming of students' information culture that is not limited to knowledge and skills in the field of information processing and implies the development of the personality, his/her preparation for professional careers in the information society.
\end{abstract}

Key words: content, informative training, tourism, information technology, information culture, Bachelor in Tourism, tourism product.

\section{INTRODUCTION}

Informatization and computerization in all spheres of human activity are the leading trends in the world economy. Humanity is entering an era of information society that has resulted in rapid development of information and telecommunication systems aimed at meeting the information needs of people. With increasing amount of information in modern society there is a growing need for highly qualified specialists with analytical thinking able to handle the necessary professional information. The important role in this process belongs to higher education as it is aimed at training specialists able to develop new information technologies and use them effectively in their professional activities.

The professional training of future specialists in tourism is also affected by the abovementioned processes as global information processes require tourism industry workers to apply new approaches to meet the needs of the tourist market. Consequently, there is a growing need for specialists in tourism possessing information culture able to create, save and effectively use information and communication technologies, develop tourism products or services. The study of foreign experience in specialists' professional training, in particular, specialists' in tourism, that requires critical analysis of achievements in education systems abroad and outlining of positive aspects of such experience, is extremely necessary for the development of higher education in Ukraine.

THE AIM OF THE STUDY

The aim of the paper is to analyze the content of Bachelors' in Tourism informative training in Ukrainian and Polish experience. 


\section{THEORETICAL FRAMEWORK AND RESEARCH METHODS}

The problem of information technologies implementation into the educational process has been studied by domestic and foreign authors (N. Alyeshugina, N. Belikov, V. Gerasimenko, G. Gurevych, J. Hebenstreit, S. Hrystochevskyi, P. Koval, V. Kucherenko, H. Mitsuhara, A. Paramythis, M. Rahkila and others).

Researches by L. Agafonov, S. Baylyk, V. Khudo, M. Malska, S. Melnychenko and O. Oliynyk reveal the impact of new information technologies on the tourism industry.

We have used research methods of theoretical analysis to select Ukrainian and Polish higher education institutions engaged in professional training of Bachelors; comparative analysis to compare the educational process of Bachelors' in Tourism training in Ukraine and Poland.

\section{RESULTS}

Tourist industry is characterized by vast amounts of information and a variety of business relations with partners, dynamic business processes, individualization of tourist services, technological improvement and high competition. Various types of information technologies, namely, global distribution systems, booking systems, electronic information systems, management information systems, mobile communication systems, online services are applied to practical activities of touristic enterprises.

According to A. Zemskov the introduction of information technologies into educational process ensures the forming of technically and technologically educated creative personalities prepared for life and active work in today information society and creates a proper framework for the development of life competency, cognitive and creative activities, self-actualization and professional self-determination based on individual capabilities and personal preferences (Zemskov, 2001).

Forming of information culture of future specialists in tourism is possible with the help of the very information technologies. Performing activities in terms of educational and information environment a student being at an early stage of informative training undergoes the process of his/her professional development in the field of information and information technologies on the new technological basis and becomes, first of all, a competent and independent user, then the information developer and, finally, an expert.

In higher education institutions of Ukraine providing undergraduate courses in tourism the content of the informative training is aimed at students' obtaining profound knowledge in "Information Technologies in Tourism". In Academy of Recreational Technologies and Law the content of Bachelors' in Tourism informative training implies mastering of "Foundations of Bachelors' in Tourism Information Culture". Students acquire practical experience in forming information culture during work placements in travel agencies (Академія рекреаційних технологій та права, 2015).

The discipline "Information Technologies in Tourism" is one of the main disciplines in training specialists in tourism industry. Its purpose consists in mastering a set of knowledge, skills and abilities necessary to improve professional activities with the help of information technologies. The main objectives of the discipline are to introduce students to the concept of information technologies in tourism, consider the types of information technologies, explain to students the circulation of information in the travel agency and advertising as information technology, form students' knowledge of information systems, acquaint students' with modern booking systems in tourism aimed at promoting Bachelors' in Tourism information competency and their readiness to professional activities.

After completing "Information Technologies in Tourism" students are to know basic concepts of information technologies; stages and main features of formation and development of the information society; multimedia technologies; organization of decision- 
making support system; software for tourist activities; classification of Internet sources for tourist orientation; features of tourism advertising. Also they must be able to apply the obtanied knowledge about the organization and the use of modern information technologies in practice to solve industrial problems; to create and distribute materials on the Internet; to work with a variety of standardized and specialized software products in tourism industry; to use automated systems for the integrated assessment of information systems and technologies used in tourism (Академія рекреаційних технологій та права, 2015).

The discipline consists of two modules. The first module "Main Directions in Development of Information Technologies and Service Activities in Tourism" is focused on the main stages of information technologies development. Thematic units of the module form future specialists' vision of content and basic definitions of the concept "information technology", main stages of information technologies (IT) development, content and concept of information, informatization in tourism, communication means, travel agencies' activities in terms of information circulation. The second module "Communications, Information Systems, Booking Systems and Advertising in Tourism" is aimed at studying peculiarities in the use of information technologies in tourism. This module includes such thematic units "Information Systems and Applications in the Tourism Business", "Databases and Database Management Systems", "Tourism Organization Advertising as Information Technology".

Quite important in the forming of Bachelors' in Tourism information culture within professional training is a variable component of 'Foundations of Bachelors' in Tourism Information Culture". The objective of the discipline consists in improving information competency of Bachelors in Tourism as well as their training for professional activities with the use of modern information sources and systems.

According to the syllabus the module "Foundations of Bachelors' in Tourism Information Culture" is studied during the 8th semester. It comprises 108 hours (3 credits) whereas 10 hours are dedicated to classroom activities, 6 hours - to lectures, 4 hours - to workshops, 58 hours - to independent work, 48 hours - individual work. At the end of the semester students are to take a credit test. It should be mentioned that the discipline deepens and refines upon the issues directly related to the forming of knowledge, abilities and skills, namely, how to operate a tour and walking tours, to create and promote tourist products.

This discipline is aimed at mastering knowledge of hardware and software of information technologies in tourism, basics of creation and operation of local and global networks, automated management systems of tourism, information security, applications for forming, promotion and implementation of tourist products, automated booking systems and using multimedia and the Internet in tourism business (Академія рекреаційних технологій та права, 2015).

After completing "Bachelors' in Tourism Information Culture" students are to know main definitions of the concept "information culture"; concepts and types of information; the process of collection, storage, processing, transmission and use of information with the use of modern equipment; foundations of tourism enterprise management etc. At the same time they should be able to create and display tourism advertising on the Internet; to use modern integrated Customer Relationship Management systems (CRM); to apply the most global distribution systems in the international tourism market; to create databases of tourism enterprises by means of MS Access.

The discipline "Foundations of Bachelors' in Tourism Information Culture" also includes two modules: "Information Technologies in Tourism Enterprise Management" and "Informatization Specificity in Tourism Activities".

The first module includes such thematic units as "Main Definitions of the Concept "Information Culture", "E-Commerce in Tourism", "Virtual Tourist Community". Its objectives 
are to reveal content and main definitions of the concept "information culture", main direction in the development of information technologies in tourism, stages of development and implementation of information systems in tourism, the Internet and e-commerce in tourism, classification of tourist resources online, e-commerce resperesentatives, electronic payments, virtual tourism communities, peculiarities of forming the information space in tourism (Академія рекреаційних технологій та права, 2015).

The second module includes such thematic units as "Geoinformation Technologies in Tourism Organization", "Use of Multimedia in Tourism Business", "Automated Booking in Tourism". Its objectives are to reveal the evolution of booking systems; characteristic and functionality of domestic and foreign booking systems; modern multimedia technologies; electronic catalogues; tourist exhibitions and fairs on the Internet; geoinformation systems: concepts, general information, fields and examples of using GIS technologies in tourism (Академія рекреаційних технологій та права, 2015). The study of the discipline "Foundations of Bachelors' in Tourism Information Culture" is the final stage in the theoretical aspect of forming Bachelors' in Tourism information culture during professional training.

Also we have studied Polish experience in informative training of Bachelors in Tourism. It has been found out that Polish universities are actively engaged in the implementation of information technologies into the professional training of specialists in tourism. According to J. Maxwell highly qualified staff plays a key role in the tourism market, especially at the time of increasing competitiveness. Therefore, management of each tourist company should invest into human capital development. J. Maxwell states that main forms for the training of specialists in tourism are trainings, e-learning, use of computers and Internet technologies (Maxwell, 2014).

In particular, at Belsk Academy named after J. Tyszkiewicz after completing courses of information technologies (IT) and marketing in the field of tourism and hospitality students obtain such knowledge and skills as effective use of Internet resources and improvement of their work through online system; new forms of online marketing and multimedia communications; creation of tourism product presentations; various electronic tools for building long-term client relationships (Bielska Wyższa Szkoła im. Józefa Tyszkiewicza, 2015). Almamer Academy trains specialists in the field "Hotel and Restaurant Business", "Tourism and Leisure". The main task of the Academy is to educate a modern manager of a tourism company, hotel and restaurant, who possess skills of using advanced information technologies, self-control, planning and implementation of organizational projects in tourism, leisure and hospitality (Almamer Szkoła Wyższa, 2015).

The students of the Cracow University of Economics obtain comprehensive knowledge of the importance of cultural heritage for modern tourism, the museum and other cultural institutions activities and have the opportunity to master skills in the management of cultural heritage objects and cultural events. The training program combines humanitarian and economic aspects of cultural tourism market (Uniwersytet Ekonomiczny w Krakowie, 2015).

In the Academy of Tourism and Hotel Management in Gdansk specialists in tourism are trained, particularly, in "Tourism and Recreation". After graduation students possess such abilities and skills necessary for professional activities in developing information projects in tourism and leisure, organizing work in the tourism enterprise, leisure, recreation and health centers (Wyższa Szkoła Turystyki i Hotelarstwa, 2015).

Cracow School of Health Promotion focuses the training of specialists in tourism on health tourism. Graduates of the school possess knowledge of natural sciences, social and economic progress in tourism, professional responsibilities in tourism and recreation; skills of tourism projects organization and implementation, content and opportunities in health tourism (Krakowska Wyższa Szkoła Promocji Zdrowia, 2015). 


\section{CONCLUSIONS}

Thus, the informative training of Bachelors in Tourism in Ukraine is focused on mastering such disciplines as "Tour Organization", "Tour Services Organization", "International Tourism", "Information Technologies in Tourism", as well as "Foundations of Bachelors' in Tourism Information Culture" etc. At the same time in Poland the informative training of Bachelors in Tourism is focused on mastering such disciplines as "Management in Tourism", "Tourism Organization", "Tourism Business Economics", "Tourism Services Organization", "Information Systems in Tourism" etc.

The results on the study of the content of specialists' in tourism informative training in Poland can be useful for developing national curricula for training Bachelors in Tourism.

Perspective for further researches we consider the study of the problem of informative training of specialists in tourism in the experience of leading European countries.

\section{REFERENCES}

1. Almamer Szkoła Wyższa [Almamer Academy]. (2015). Kierunek turystyka $i$ rekreacja specjalności z zakresu: hotelarstwo i gastronomia, turystyka i rekreacja studia $i$ stopnia, ii stopnia - stacjonarne i niestacjonarne [Tourism and Recreation Specialization in such Fields as Hotels and Catering, Tourism and Recreation Studies of the First and Second Degrees - Full-time and Part-time]. Retrieved 5.12.2015 from : http://www.almamer.pl/ rek_turystyka_i_rekreacja.php.

2. Bielska Wyższa Szkoła im. Józefa Tyszkiewicza [Belsk Academy named after J. Tyszkiewicz]. (2015). Informatyka i marketing w turystyce $i$ hotelarstwie. Wellness i SPA [Information and Marketing in Tourism and Hotel Management. Wellness and SPA]. Retrieved 5.12.2015 from : http://www.podyplomowe.tyszkiewicz.edu.pl/index.php?option $=$ com_content\&view $=$ article\&id $=48 \&$ Itemid $=30$.

3. Krakowska Wyższa Szkoła Promocji Zdrowia [Cracow School of Health Promotion]. (2015). Turystyka i rekreacja [Tourism and Recreation]. Retrieved 5.12.2015 from : http://www.kwspz.pl/kandydaci/informacje-podstawowe/studia-

licencjackie/turystyka-i-rekreacja./

4. Maxwell, J. (2014). Szkolenia w turystyce - to się naprawdę oplaca! [Training in Tourism - It Really Pays Off!]. Retrieved 5.12.2015 from : http://www.rynekturystyczny.pl/artykul/8535/szkolenia-w-turystyce-to-sie-naprawde-oplaca.html.

5. Uniwersytet Ekonomiczny w Krakowie [Cracow University of Economics]. (2015). Obstuga kulturowych form turystyki [Support of Tourism Cultural Forms]. Retrieved 5.12.2015 from : http://nowa.uek.krakow.pl/pl/uczelnia/wydzialy/wydzial-zarzadzania/wydzial/ katedry/katedra-turystyki/specjalnosci-na-tir/obsluga-kulturowych-form-turystyki.html

6. Wyższa Szkoła Turystyki i Hotelarstwa [Academy of Tourism and Hotel Management]. (2015). Oferta Edukacyjna - Studia I Stopnia - Kierunek Turystyka i Rekreacja [Education - Undergraduate Courses - Tourism and Recreation]. Retrieved 5.12.2015 from : http://wstih.pl/oferta-edukacyjna/studia-I-stopnia/kierunek-turystyka-i-rekreacja.

7. Академія рекреаційних технологій та права [Academy of Recreational Technologies and Law]. (2015). Туризм [Tourism]. Retrieved 5.12.2015 from : http://artip.lutsk.ua/pages/turizm.

8. Земсков, А., Шрайберг, Я. (2001). Электронные библиотеки: учеб. пособ. [Electronic Libraries: Textbook]. M., 91 p. (in Russian). 